\title{
Prospect of Natural Killer Cells in Cancer Immunotherapy
}

\author{
Anna Meiliana ${ }^{1,2, *}$, Nurrani Mustika Dewi², Andi Wijaya ${ }^{1,2}$ \\ ${ }^{1}$ Postgraduate Program in Clinical Pharmacy, Padjadjaran University, Jl. Eijkman No.38, Bandung, Indonesia \\ ${ }^{2}$ Prodia Clinical Laboratory, Jl. Cisangkuy No.2, Bandung, Indonesia \\ ${ }^{*}$ Corresponding author. E-mail: anna.meiliana@prodia.co.id
}

Received date: Sep 3, 2018; Revised date: Dec 4, 2018; Accepted date: Dec 10, 2018

\section{Abstract}

B ACKGROUND: Current understanding in molecular character of natural killer (NK) cell, its function and mechanisms, send people the ideas to develop a NK-cell-based immunotherapeutic strategies against human cancer.

CONTENT: Before being regards as a cell-based cellular therapy, NK cell have to be clinical proven. Early studies with NK cells infusions for acute myeloid leukemia and lung cancer showed a promising result. NK cells need simplified methods for enriching and expanding, in addition to its transfection with chimeric antigen receptors (CARs). NK-92 arise as an assuring effector cells to augment monoclonal and bispecific antibody therapy. Thus, NK cells show a potential opportunity for cell engineering, outstep the era of $\mathrm{T}$ cells.

SUMMARY: It is believed that NK cells bring a bright hope for future cancer immunotherapies, either alone or in combination as a harmonious therapy.

KEYWORDS: NK cells, NK-92 cells, immunotherapy, CAR

Indones Biomed J. 2018; 10(3): 192-202

\section{Introduction}

Current achievement in immunology promoted the immune cells as powerful therapeutic antigens, targeting tumor antigens with $\mathrm{T}$ cells expressing chimeric antigen receptors (CARs), especially in lymphoid malignancies patients.(1-3) However, a potentially fatal cytokine release syndrome was reported in a significant number of subjects and requiring intensive care unit (ICU) admission. Then, despites its promising results in treating cancer, this give a big challenge to enact it available for a larger number of patients.(4)

Increasingly considered as promising immunotherapeutic agents for cancer, Natural Killer (NK) cells have advantages because they are potentially broadly applicable and do not cause graft-versus-host disease such as other T cells counterparts.(5) NK cells have an important role in cancer immunosurveillance as a part of innate immune system. $(6,7)$ They don't need peptide antigen to be presented in major histocompatibility complex (MHC) molecules foregoing, because their activity were controlled by distinct germline-encoded cell surface receptors so the healthy and diseased tissue can be distinguished. $(8,9)$ The problem is, in cancer patients, the immunosuppressive tumor microenvironment was generally impaired, so the NK cell responses were also impaired. That's why current NK cell therapies were commonly performed with allogeneic adoptive transfer from a suitable donor's NK cell which had expanded ex vivo.(10-12)

Primary NK cells usually have a limited of life span and expansion potential, but the NK cell line NK-92, with help of interleukin (IL)-2 can be continuously expanded in a good manufacturing practices (GMP)-compliant process. (13) Early phase clinical trials for safety and clinical activity of NK-92 cells for allogeneic therapy in patients with advanced malignancies showed a good result.(1315) Preclinical studies using both NK-92 primary human NK cells and investigating the generating of cluster of 
differentiation (CD)19-specific chimeric antigen receptors (+) NK cells.(16-18) By that, compared than limited original $\mathrm{T}$ cells (17-21), CAR-engineered cells can be isolated and expanded from bulk of non-transduced cells (19-22). Thus, donor-derived allogeneic cells immunotherapy were being preferred for adoptive cancer because the cells do not recognize tumor cells as 'self', and can bypassing inhibitory signals. $(10,11)$ This advantage may be extended to NK-92 cells that do not express most of the inhibitory killer cell immunoglobulin-like receptors (KIRs) and phenotypically resemble activated NK cells. $(5,23)$ This approach could be potentially utilized for solid tumor or hemotological malignancies cases, where CAR-engineered NK-92 cells will target antigens expressed by cancer cells.(17,19,20,2428)

\section{Human Natural Killers Cells}

The immune system is divided into two parts, called the acquired immune system and the innate immune system. Innate immunity was typically characterized with a broadly distributed variety of myeloid and lymphoid cells and the rapid responses through a defined repository of germlineencoded receptors. In the contrary, adaptive immunity in mammals was defined by two lymphocytes, $\mathrm{T}$ and $\mathrm{B}$ cells.
$\mathrm{T}$ cell receptor (TCR) and antibody/B cell receptor (BCR) produced by the site-specific somatic recombination of these cells.(29)

NK cells first illustrated as large granular lymphocytes, and has natural cytotoxicity to counter tumor cells. Later on people recognized NK cells as a separate lymphocyte lineage with cytokine-producing effector function besides its cytotoxicity (Figure 1).(29,30) NK cell activity regulation including the NK cell detection system involving the activation of a variety of cell surface and the inhibitory receptors. There will be an equilibrium between the integration of antagonistic pathways upon interaction with neighboring cells to decide the activation of NK cells to kill target cells.(31) When activated, NK cell receptors will detect a distress on cells ligands, for example the stress-induced self ligands which recognized by some slert molecules like the NK group 2D (NKG2D).(32) There are also alert molecules such as nonself ligands (the cytomegalovirus-encoded m157 recognized by Ly49H in the mouse) and Toll-like receptor (TLR) ligands. Naturally, NK cells express several TLRs which can induces interferon (IFN)- $\gamma$ production and enhances cytotoxicity in vitro.(33)

Like any other lymphocytes, during their development NK cell acquire tolerance to self. This does not always occur but NK cell have the potential to attack normal self cells.(34) NK cells utilize the absence mensuration of consecutively

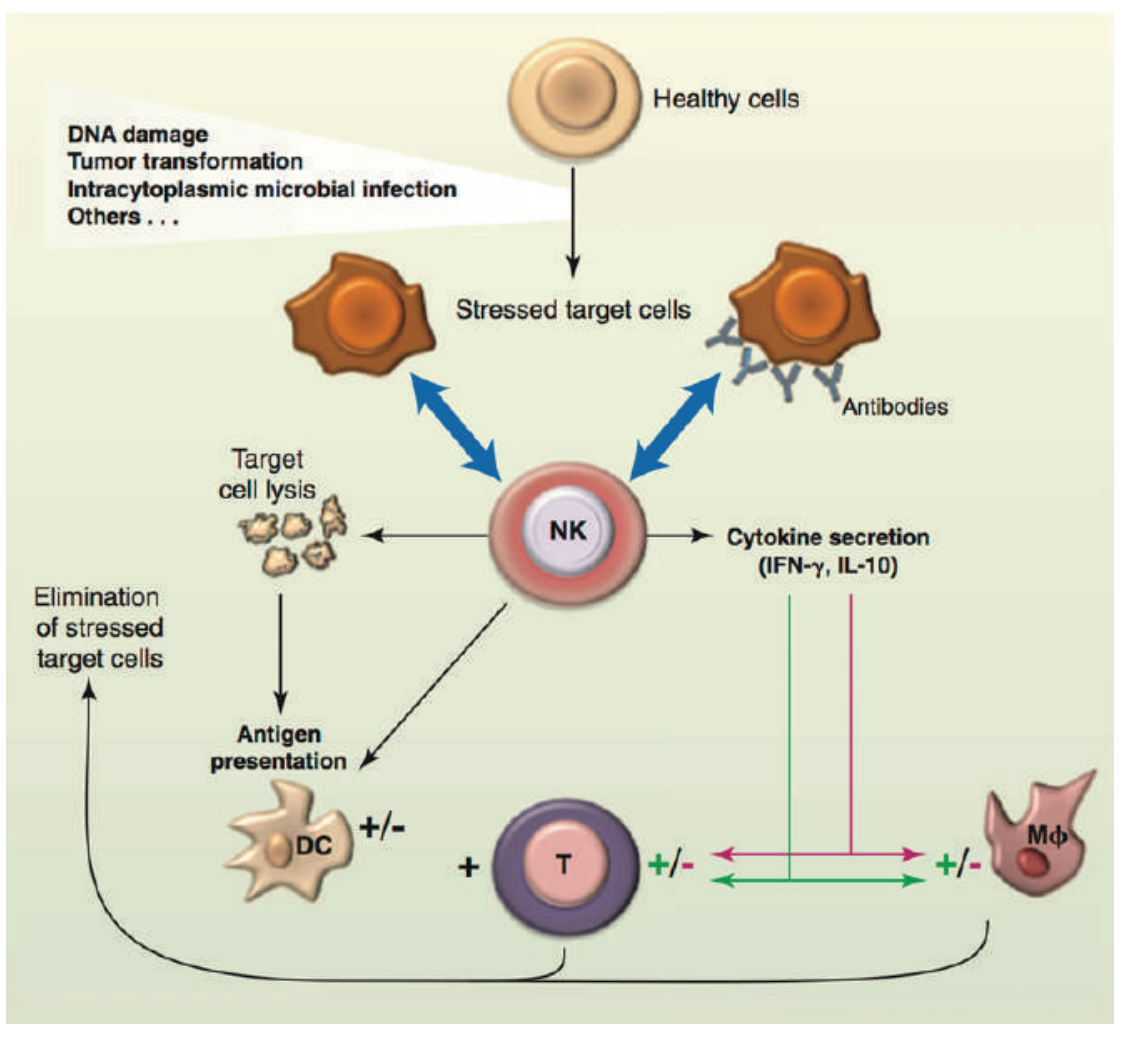

Figure 1. The biological functions of NK cells. NK cells can recognize a variety of stressed cells in the absence or in the presence of antibodies (blue arrows). NK cell activation triggered by this recognition can lead to the lysis of the target cell and to the production of various cytokines and chemokines depending on the nature of the stimulation.(29) (Adapted with permission from American Association for the Advancement of Science). 
expression of self's molecule on susceptible target cells. In several in vitro and in vivo models, MHC class I-specific receptors expressed by NK cells lose its inhibitory signals when encountering hematopoietic cells with MHC class I-deficient. This usually happened when cells were flustered due to viral infection or cellular transformation. $(35,36)$ The fallout effects, this missing self on hematopoietic cells will be recognized by NK cells.(37) This recognition happened due to the NK cells inhibitor receptors specific to MHC class I, including KIRs in humans, lectin-like Ly49 molecules in mice, and CD94/NKG2A heterodimers in both species. $(38,39)$ The MHC class I-specific inhibitory receptors include the KIRs in humans, the lectin-like Ly49 dimers in the mouse and the lectin-like CD94-NKG2A heterodimers in both species (Figure 2).(35,36)

Intracytoplasmic Immunoreceptor tyrosine-based inhibitions motifs (ITIMs) mediates the signal to activate the large family of inhibitory receptors including MHC class I receptors.(31) Therefore NK cell can distinguish and spare healthy cells which express self MHC class I molecules accompanied by low amounts of stress-induced self molecules, while dejected cells with down-regulated MHC class I molecules and/or high level of stress-induced self molecules, such as NKG2D ligands.(40) Figure 3 shows a diagram describing balance of inhibitory and stimulatory signals received by a natural killer.

So we've figure out that NK cells can influence the host's immune response via cytokine and chemokine and kill certain infected or transformed cells through perforin/ granzyme or death receptors-related pathways such as Fas, and tumor necrosis factor (TNF)-related apoptosisinducing ligand (TRAIL).(40-46) The prototypic cytokine secreted by NK cells is IFN- $\gamma$. It has the ability to shape the Th1 immune response (44), activate antigen-presenting cell (APC) for MHC class I further upregulate expression (47), activate macrophages to kill the restricted intracellular pathogens (48), and anti-proliferating effect on viral and malignant-transformed cells (49).

NK cells in human is phenotypically and functionally heterogeneous. NK cells which were rich with $\mathrm{CD} 56^{+}$ surface molecules were primarily cytokine-secreting cells, found about $10 \%$ NK cells found in blood, and almost $100 \%$ in secondary lymphoid tissues. They can be activated within minutes to secrete cytokines and chemokines, but these $\mathrm{CD} 3^{-} \mathrm{CD} 56^{+} \mathrm{NKp} 46^{+}$cells barely can spontaneously kill tumor cell targets.(50) Otherwise, Circulating NK

\section{Activating receptors}

Receptors
NKp46
CD16
h NKp30
h NKp44
h NKp80
m NKR-P1C
NKG2D
m NKG2D-S
h KIR-S
m Act. Ly49
CD94/NKG2C
CRACC
Ly9
CD84
NTBA
2B4

Adaptors $\mathrm{CD} 3 \zeta, \mathrm{FcR} \gamma$ $\mathrm{CD} 3 \zeta, \mathrm{FcR} \gamma$ $\mathrm{CD} 3 \zeta, \mathrm{FcR} \gamma$ DAP12

$\mathrm{FcR} \gamma$ DAP10

DAP12

DAP12 DAP12, DAP10

DAP12 SAP, EAT2 SAP SAP, EAT2 SAP SAP, EAT2, ERT

Cytokine receptors IL-1R IL-2R

IL-12R IL-15R IL-18R IL-21R IFNAR

\section{Inhibitory receptors}

h KIR-L

h LILRB1

CD94/NKG2A

$\mathrm{m}$ Inh. Ly49

m NKR-P1B

m NKR-P1D

KLRG-1

TIGIT

CEACAM-1

LAIR-1

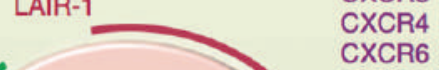

Chemotactic receptors

CCR2

CCR5

CCR7

CXCR1

CXCR3

CXCR4

CXCR6

CX3CR1

h Chem23R

S1P5
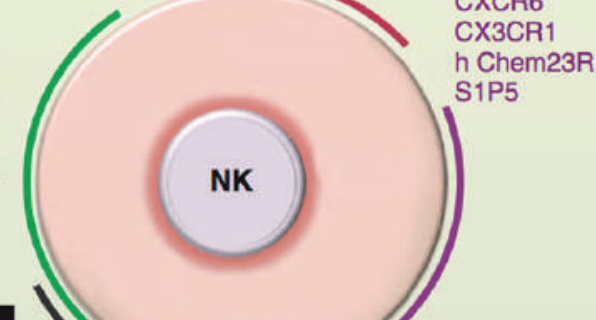

Figure 2. NK cell receptors. NK cells express many cell surface receptors that can be grouped into activating (green), inhibitory (red), adhesion (blue), cytokine (black) and chemotactic receptors (purple). In addition to MHC class I-specific receptors, other NK cell inhibitory receptors specific for non-MHC ligands also regulate NK cell reactivity.(29) (Adapted with permission from American Association for the Advancement of Science). 


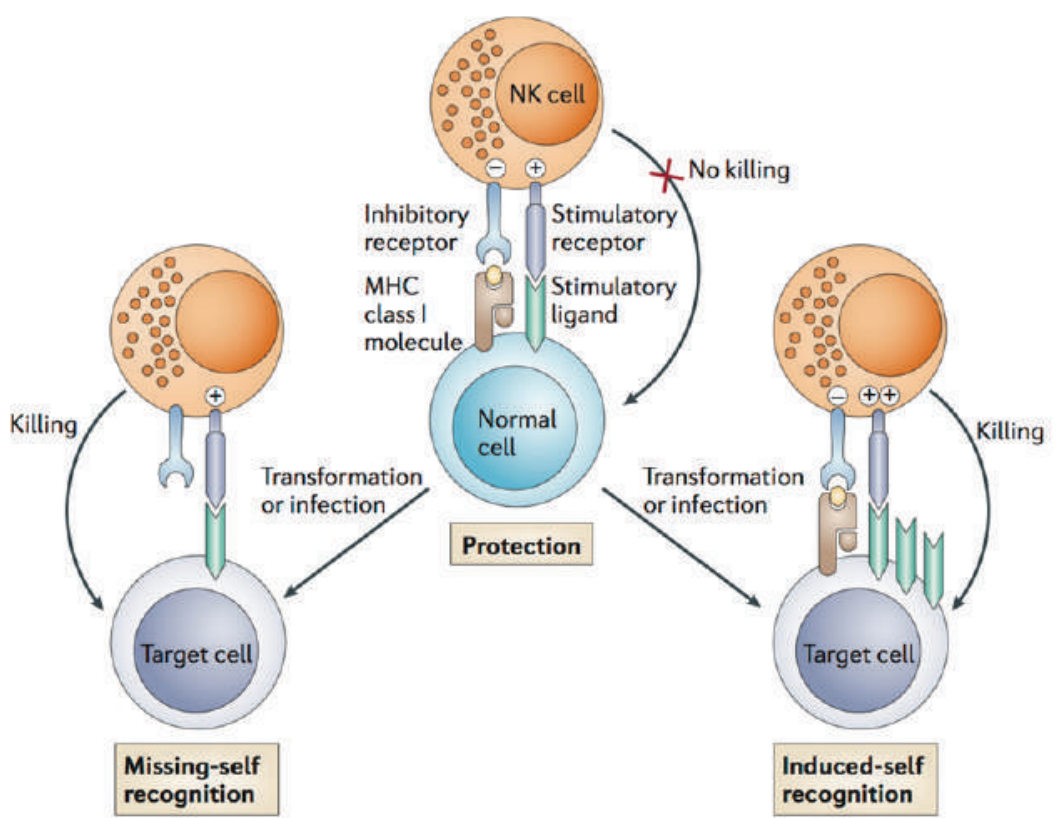

Figure 3. The balance of inhibitory and stimulatory signals received by a natural killer cell determines the outcome of interactions with target cells.(37) (Adapted with permission from Springer International Publishing AG). cells with low surface density (called dim expression of CD56 and NKp46) does not express cytokines as agile as the other type but some, but not all, have the ability to lyse susceptible tumor cell targets sprightly.(51) however both types have relatively distinct and balanced important roles during human immune response.(52-55) despite its cytokine secretion or cytotoxicity, NK cell was tightly regulated by the balancing of its activation and inhibition signals which are integrated in a complex network expressed from its cell surface receptors, and we have the ideas that the immune system can be engineered to cure some forms of cancer.(56)

\section{Targeting NK Cells in Cancer Immunotherapy}

Formerly, people pit most attention at $\mathrm{T}$ lymphocytes for immunotherapy strategies, but new discoveries showed the potential of NK cells as better effector cells for treating cancer. The cytotoxicity effects, together with cytokine secretion, especially IFN and granulocyte-macrophage colony-stimulating factor, assign them at the crossroads of innate and adaptive immunity. Through antibody-mediated cellular cytotoxicity, the activity of monoclonal antibody can be enhancing and can be transfected with chimeric antigen receptors.(57) As their name suggests, NK cells spontaneously kill cells deemed to be dangerous to the host (cancer, foreign or virus-infected cells) and thus are presumed to be key effectors in cancer immunosurveillance, transplantation rejection and early viral immunity.(33)
NK cells are usually defined as $\mathrm{CD}^{-} \mathrm{CD} 56^{+}$cells in humans and $\mathrm{CD}^{-} \mathrm{NK} 1.1^{+}$or $\mathrm{CD} 3^{-} \mathrm{NKp} 46^{+}$cells in mice. $\mathrm{CD} 56^{\mathrm{lo}} \mathrm{CD} 16^{+} \mathrm{NK}$ cells with high cytotoxic potential mostly found in human blood, whereas the immunomodulatory $\mathrm{CD} 56^{\mathrm{hi}} \mathrm{CD} 16^{-}$subset found more in lymph nodes. NK cells serve as $5-15 \%$ of human circulating lymphocytes, classified as different population based in their maturation and specific function. $(58,59)$

NK cells have developed several mechanisms for distinguishing healthy cells from target cells. These mechanisms form the basis of NK cell activation and cannot be considered in isolation but instead must be considered as complex integration of signals from an array of receptors. By binding with self MHC class I, NK cells tolerate to selftissue and allows the licensing of NK cells by the engagement with MHC class I. Cells with downregulated expression of MHC class I such as in malignant cells, will put the NK cells inhibitory signals off and permit their function. $(37,38)$

Granzyme B and perforin are the core molecules required for NK cell-mediated tumor killing (60), although death-receptor pathways (involving FasL and TRAIL) are sometimes used. Furthermore, NK cells secrete proinflammatory cytokines and chemokines (such as IFN- $\gamma$, TNF, IL-6, granulocyte-macrophage colony-stimulating factor (GM-CSF) and chemokineC-C motifligand 5 (CCL5)) that might exert direct anti-tumor activity in addition to promoting innate and adaptive responses. Thus, NK cells are not only killers but also immunoregulatory cells that can positively or negatively influence anti-cancer responses by modulating the responses of dendritic cells (DCs) and T cells. 
(61) Another mechanism linked to the immunosurveillance of cancer by NK cells involves the elimination of senescent cells. Indeed, the cytokines and chemokines associated with the senescence-associated secretory phenotype mobilize effective NK cell responses (62).

NK cells can be derived from various sources and can be obtained from the patient (autologous setting) or from a healthy donor (allogeneic setting). Few NK cells circulate in human blood, and naive NK cells exhibit limited cytotoxic activity. For these reasons, several protocols have been designed to expand large numbers of NK cells with full anti-tumor functions. These methods have been discussed before. $(63,64)$ Previous trials showed that NK cells autologous infusion are clinically ineffective, even with concomitant administration of cytokines such as IL-2.(6567) Thus the focus shifted to allogeneic administration from donor, usually obtained by apheresis to obtain mononuclear cells, majority peripheral blood mononuclear cells (PBMC). There are still challenges including to consistently obtain sufficient numbers of cells for patient treatment, as we know NK cells only present approximately $10 \%$ of all lymphocytes in the blood, and the other issue is to remove T cells which can induce Graft versus host disease (GvHD) in the recipient, commonly using negative CD3 depletion using immunomagnetic antibody tagging with subsequent absorption of the cells over a magnetic column (i.e., the Miltenyi CliniMACS system, Bergisch-Gladbach, Germany).(68,69)

Recently the interest shifted to NK cells from umbilical cord blood which is readily available with no risk or aggravation for donor. Frozen cord blood cells either cryopreserved or not, can serve as starting material. NK cells in cord blood are immature, so they must be cultured for several weeks with a cocktail of cytokines which contains a combination of IL-2, IL-15, FMS-like tyrosine kinase 3 ligand (Flt-3L) and IL-3 on positively selected cord blood NK cells were placed on a feeder layer of mesenchymal stromal cells, until reach an acceptable NK cell numbers, average at a median of 60 -fold. $(57,70)$

However, this expansion process is costly and burdensome, restricted process in a GMP-standard laboratory, performed in gas-permeable bags, in flasks or in bioreactors that expand larger cell numbers on a smaller footprint. To reduce the cost, any manipulation must be done before culture expansion, so the material and time cost will be less. The bag system is a good choice for it does not need wide spaces for sterile and closed system. Some company offers automated technology for cell expansion including Milteny's Prodigy (Miltenyi Biotec $\mathrm{GmbH}$, Bergisch-
Gladbach, Germany) with their closed system in constant medium and cytokine feed as per program, and the G-Rex biorecator (Wilson Wolf Manufacturing, New Brighton, MN, USA) expands NK cells well and simplified medium change as the cells collect at the bottom of the flask.(71)

Furthermore, with the help of cytokines and certain growth factors, adoptively transferred NK cells can be expanded and activated in vivo in conditioned patients, or may also combined with other treatment modalities to reach a synergistic antitumor activities.(72)

\section{NK-92 Cell Line, "Off-The-Shelf" for Adoptive NK Cells-based Cancer Immunotherapy}

Recalling the cytotoxic features of NK cells as part of innate immunity system, they don't need prior sensitization to kill any virally infected cells and tumor cells. Adequate number of functional NK cells that are able to proliferate in vivo were needed for an effective therapy but are not overstimulated by cytokines. $(73,74)$ Some group study attempt to optimizing methods for NK cells ex vivo isolation, activation and expansion from peripheral blood, mainly for prevention and/or treatment of relapsed disease. $(75,76)$ Another study using IL-2 and an artificial antigen presenting cell to expand umbilical cord blood NK cells ex vivo.(78) Particularly, there are two ongoing clinical trials testing the feasibility (NCT01619761 and NCT01729091). Apheresis become the most preferred method for collecting PBMNCs due to its ability to collect cells aseptically into a closed system and minimizing the contamination.(79)

Previous experiences demonstrated that concomitant administration of cytokines such as IL-2, for NK cells autologous infusion are clinically ineffective (65), then the focus shifted to allogeneic therapy. In this case, graftversus-host disease in the recipient have to be prevented, by adding some manipulation steps in expansion process.(68) Substantial donor-dependent variability also found in terms of NK cell yield, so a continuously growing NK cell line is needed to provide predictable numbers of highly cytotoxic NK cells on expansion. $(15,68,69,80-82)$.

Domogala, et al., tried to modify the NK cells differentiation protocol, and compared the mobilized peripheral blood stem cells (mPBSC), fresh $\mathrm{CB} \mathrm{CD} 34^{+}$cells and frozen umbilical cord blood $\mathrm{CD} 34^{+}$cells to generate a functional, readily available off-the-shelf product of NK cells, and found that the best source for NK cells is frozen umbilical cord blood $\mathrm{CD} 34^{+}$cells, suggested that 
the cryopreservation procedure selected the most potent $\mathrm{UCB}$ CD $34^{+}$cells, leading to a higher fold expansion (600 versus 200) therefore generated a higher NK cell numbers, not regarding the phenotype, cytokine production or cytotoxicity of the cells. $(83,84)$

NK cell proliferation ex vivo can generally be stimulated using a feeder cell such as monocytes which stimulate NK cell expansion by both humoral signals and direct cell-to-cell contact. That's why some protocols suggest the using of PBMNCs as a source of feeder cells in the NK cell culture. $(65,85-87)$ Moreover, two allogeneic feeder cell lines commonly used in NK cell expansion including an Epstein-Barr virus-transformed lymphoblastoid cell line and an engineered leukemic cell line that express a membranebound form of IL-15 fused to the T cell receptor CD8a and the 41BB ligand.(88-90) Using allogeneic feeder cell lines requires irradiation, meanwhile autologous feeder cell lines do not need it. $(69,88-91)$

NK-92 is a highly potent permanent NK cell line (NantKwest, Culver City, CA, USA), which is now readily available, processed from a cGMP-compliant master cell bank, predictable and reproducible amplification of an extensively characterized potent NK cell agent is at hand for clinical usage.(5) It is a permanent, IL-2-dependent NK cell line, first obtained from the peripheral blood of a 50-year-old male patient with non-Hodgkin's lymphoma at diagnosis in 1992, and can be kept in vented tissue culture asks. $(92,93)$ NK-92 is characterized by the expression of $\mathrm{CD}_{56}{ }^{+}$and $\mathrm{CD} 2, \mathrm{CD} 3, \mathrm{CD} 8$, and and the low-affinity immunoglobulin $\mathrm{G}$ (IgG) fragment crystallizable region (Fc) receptor (FcyRIII), CD16.(23) A CD56 ${ }^{+} / \mathrm{CD} 16 \% /$ low phenotype is typical for a minor subset of NK cells in peripheral blood, which have immunomodulatory functions as cytokine producers.
However, NK-92 is a highly cytotoxic cell line. It expressed high levels of cytolytic pathway molecules, including perforin and granzyme B. NK-92 clone transformation may have emerged from an early undifferentiated NK cell progenitor.(13,23) CD16 receptor is an important feature of NK cells that mediates binding to antibodies through the Fc portion of IgG so it may have an additional killing mechanism of antibody-dependent cellmediated cytotoxicity (ADCC) in conjunction with tumortargeting antibodies. Different with primary cytotoxic NK cells, ADCC originally is not a cytotoxic mechanism naturally exerted by currently established NK cell lines (Figure 4).(5) Uniquely, other established cytotoxic NK cell lines, such as KHYG-1, NKL and YT, have inadequate of CD16 expression.(94)

NK-92 cells can be easily manipulated genetically for specific tumor antigens recognition, or to develop antibodydependent cellular cytotoxicity. It has low risks and can be easily infused into patients, even in the advanced stage of cancer.(4) NK cell can be engineered to express many different CARs to prevent tumor resistance, by targeting for instance, CD19 or CD20 (anti-B cell malignancies), CD38 (anti-myeloma) or human epidermal growth factor receptor 2 (HER2; ErbB2; anti-epithelial cancers), with lower costs compared to autologous or allogeneic NK cells and, particularly, CAR-T cells make it as a promising effective treatments in cancer.(5)

\section{CAR-expressing NK Cells}

On August 2017, the forst CAR-T therapy approved in United States was Kymriah (tisagenlecleucel) from Novartis. Without a phase 3 trial and within just six

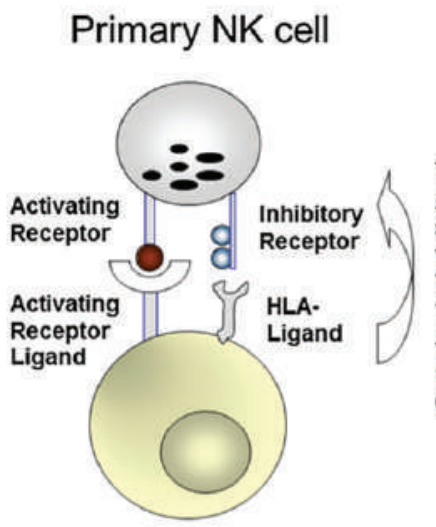

Tumor target cell

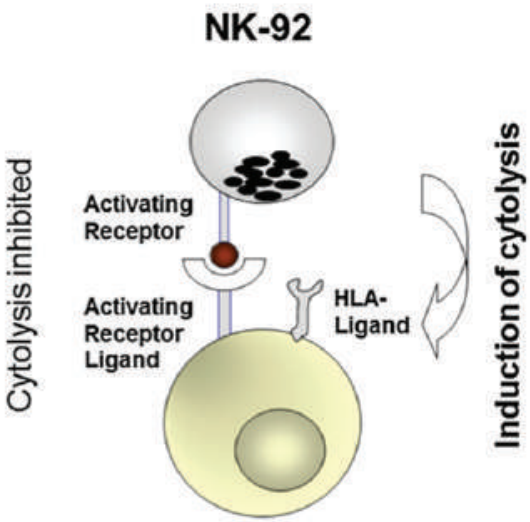

Tumor target cell
Figure 4. Simplified, schematic representation of NK-92 in a tumor target cell encounter compared to a primary NK-cell.(5) (Adapted with permission from Springer International Publishing AG). 
month the approval was achieved, due to the astonishing patients' clinical responses. After three months' treatment with Kymriah, $\sim 83 \%$ of pediatric and adult patients (up to 25 years old) 25 with relapsed or refractory B cell acute lymphoblastic leukemia (ALL) showed sufficient remission and curative therapy are adequate. In that event, soon Kite Pharma was acquired by Gilead Sciences, as a sign the industry believe that Kymriah will lead to other CARs. For CAR-T itself, a successfully overcome immunosuppressive tumor microenvironments, address the heterogeneity of solid tumors and incorporate a wider range of antigens suitable for tumor targeting, to treat leukemia auspiciously.(95)

NK cells may serve as a better alternative than CARdriven cytolysis. Allogeneic NK cells will induce the immune response and then be rejected after few days, while autologous NK cells will disappear after few days in line with its lifetime. Superior rather than T cells, NK cells' spontaneous cytotoxicity activity can trigger the demise of target cells in a tumor associated antigens (TAA)-unrestricted manner via specific natural cytotoxicity receptors (NCRs), including NCR3 (also known as NKp30), NCR2 (also known as NKp44), NCR1 (also known as NKp46), and killer cell lectin-like receptor subfamily K, member 1 (KLRK1, best known as NKG2D). NK cells express Fc fragment of IgG, low affinity III, receptor (Fc $\gamma \mathrm{RIII})$, that binds the Fc fragment of antibodies to elicit ADCC. NK cells owned the CAR-expressing NK cells and a TAA-specific monoclonal antibody, enable the combinations of two targeted therapies recognizing different (or the same) TAA(s).

The cytokines produced by NK cells are different than those from T cells, supporting the serial killing of NK cell, as the time-lapse videomicroscopy studies showed NK cells and NK-92 diligently move from one target to the next one, killing on as many as 7-10 cells. $(96,97)$ CAR-modified NK cells were in advance complementing the therapeutic option to CAR-expressing T cells, applied to fight against CD19, CD20, CD244, and HER2 as well as CAR-expressing NK92 cells targeting a broader range of cancer antigens.

NK-92 cells offer an excellence chance to be an open platform CAR-based immunotherapy.(19) It has a higher efficiency in transfection and technically simple, giving better results while enriching, and also less risk of oncogene activation and insertional mutagenesis by avoiding viral vectors.(17,19,97) Continuously expanded CAR NK-92 can be clinical useful for treating cancer patients, especially when the suitable donors for CAR T cell was impossible. In phase I clinical trials, only a minority of cancer patients treated by repeated infusion of parental NK-92 cells developed anti-HLA antibodies, and no adverse events related to immune responses to these cells were observed. $(14,15)$ This advantage may also be seen with CAR NK-92 cells. NK-92 has a high and consistent cytotoxic activity expressing CD19-specific CARs that employ CD3 or CD28CD3 signaling domains attacking established and primary B-cell lymphoma and leukemia cells more effectively compare to a similar CD137-CD3 CAR.(12)

CAR-modified NK-92 cells showed a potency of effectively treating any other types of cancer as CARengineered NK cell lines (e.g., NK-92) glioblastoma for glioblastoma, GD2-CAR on NK-92 cells against neuroblastoma, CS1-CAR-expressing NK-92 cells to target multiple myeloma (MM) cells, and an adoptive transfer of CS1-CAR-modified NK-92 cells efficiently impeded the dissemination of human IM9 MM cells in vivo and prolonged the lifespan. $(27,28)$ Retargeting of NK-92 cells to solid tumors-derived cells with a Her-2/neu-specific CAR resulted in efficient lysis of NK-resistant, ErbB2/ HER2-expressing target cells in vitro, and improved tumor localization and anti-tumoral activity in vivo. $(19,99)$ The ErbB2/HER2 specific CAR NK-92 cells has reached phase I clinical trials with cGMP requirements $(20,100)$.

\section{Therapeutic Aplication of NK Cells}

Alloreactive NK cells win the interest as suitable and powerful effector cells for cellular therapy of cancer after hematopoietic stem cells, dendritic cells, mesenchymal stromal cells, unselected $\mathrm{T}$ lymphocytes, and antigenspecific or regulatory T cells.(101) Have no risk of GvHD and having strong activity of cytotoxicity, NK cells efficiently and specifically redirected to recombine with CARs, which consist of a single-chain variable fragment (scFv; ectodomain) linked to intracellular signaling domains (endodomain).(101-104) The scFv binds to a defined target antigen on, i.e., cancer cells and triggers effector cell activation upon target engagement. $(98,105)$ Compared to cytokine-induced killer cells, that oving more actively than NK cells, it killed both MHC-I-negative and -positive cancer cells, while NK cells destroyed MHC-I-negative cells only. Moreover, cytokine-induced killer (CIK) cells moved in all directions thus left longer tracks than did NK cells. CIK cells showed higher displacement and straightness scores than did NK cells, which indicates long-distance random migration of CIK cells.(106) 
The potential NK cells currently has been translated into clinical-scale using cGMP using a variety of starting materials, technologies, and manipulations.(68) The cell line NK-92 as the most potent and promising therapeutic cell stand as master cell, thoroughly standardized and characterized.(82) After irradiation, it can be infused allogeneic to patients.(14) to ensure the product's safety, quality control become an important part include sterility testing, viability, gram stain, mycoplasma testing (for long-term cultures and products utilizing animal-derived reagents), endotoxin testing (LAL Kinetic-QCL, Lonza, Walkersville, MD) and sorting the cell phenotype as determined by flow cytometry. $(68,107)$ Another challenge for successful therapy with NK cells in mainstream clinical applications include to find the most efficient and optimal method to yield enough cells that clinically relevant, i.e., with highest tumor cytotoxicity level. The exciting future was saw as NK cells immunotherapy now marching from treating hematologic malignancy to solid tumor as well. The challenge ahead is how to optimally activate NK cells endogenously without the use of a cell infusion, perhaps by utilizing IL-15 or any promising proteins.(108)

\section{Conclusion}

NK cells as a part of immune system play a role in the first defense against diseases, including malignancies. NK cells provide an immediate natural response of cytolytic action. Recently, cell-based therapies increasingly favored and important as the promising treatment for cancer. An improved understanding of NK cell character and mechanism will promote to a clinical applications of this approach. Eventually, it might even discovered that both these cell types have their place in the multimodal approach that is required to eliminate cancer and control its recurrence.

\section{References}

1. Brentjens RJ, Davila ML, Riviere I, Park J, Wang X, Cowell LG, et al. CD19-targeted $\mathrm{T}$ cells rapidly induce molecular remissions in adults with chemotherapy-refractory acute lymphoblastic leukemia. Sci Transl Med. 2013; 5: 177ra38. doi: 10.1126/ scitranslmed.3005930.

2. Kalos M, Levine BL, Porter DL, Katz S, Grupp SA, Bagg A, et al. $\mathrm{T}$ cells with chimeric antigen receptors have poten antitumor effects and can establish memory in patients with advanced leukemia. Sci Transl Med. 2011; 3: 95ra73. doi:10.1126/ scitranslmed.3002842.

3. Kochenderfer JN, Dudley ME, Feldman SA, Wilson WH, Spaner DE, Maric I, et al. B-cell depletion and remissions of malignancy along with cytokine-associated toxicity in a clinical trial of anti-CD19 chimeric-anti-gen-receptor-transduced T cells. Blood. 2012; 119: 2709-20.

4. Klingemann H, Boissal L, Toneguzzo F. Natural killer cells for immunotherapy - advantages of the NK-92 cell line over blood NK cells. Front Immunol. 2016; 7: 91. doi: 10.3389/fimmu.2016.00091.

5. Suck G, Odendahi M, Nowakowska P, Seidi C, Wels WS, Klingeman HG, et al. NK-92: an 'off-the-shelf therapeutic' for adoptive natural killer cell-based cancer immunotherapy. Cancer Immunol Immunother. 2015; 65: 485-92.

6. Vivier E, Ugolini S, Blaise D, Chabannon C, Brossay L. Targeting natural killer cells and natural killer $\mathrm{T}$ cells in cancer. Nat Rev Immunol. 2012; 12: 239-52.

7. Iannello A, Thompson TW, Ardolino M, Marcus A, Raulet DH. Immunosurveillance and immunotherapy of tumors by innate immune cells. Curr Opin Immunol. 2016; 38: 52-8.

8. Koch J, Steinle A, Watzl C, Mandelboim O. Activating natural cytotoxicity receptors of natural killer cells in cancer and infection. Trends Immunol. 2013; 34: 182-91.

9. Shifrin N, Raulet DH, Ardolino M. NK cell self tolerance, responsiveness and missing self recognition. Semin Immunol. 2014; $26: 138-44$

10. Davis ZB, Felices M, Verneris MR, Miller JS. Natural killer cell adoptive transfer therapy: exploiting the first line of defense against cancer. Cancer J. 2015; 21: 486-91.

11. Velardi A, Ruggeri L, Mancusi A, Aversa F, Christiansen FT. Natural killer cell allorecognition of missing self in allogeneic hematopoietic transplantation: a tool for immunotherapy of leukemia. Curr Opin Immunol. 2009; 21: 525-30.

12. Oelsner S, Friede M, Zhang C, Wagner J, Badura S, Bader P, et al. Continuously expanding CAR NK-92 cells display selective cytotoxicity against B-cell leukemia and lymphoma. Cytotherapy. 2017; 19: 235-49

13. Tonn T, Becker S, Esser R, Schwabe D, Seifried E. Cellular immunotherapy of malignancies using the clonal natural killer cell line NK-92. J Hematother Stem Cell Res. 2001; 10: 535-44.

14. Arai S, Meagher R, Swearingen M, Myint H, Rich E, Martinson J, et al. Infusion of the allogeneic cell line NK-92 in patients with advanced renal cell cancer or melanoma: a phase I trial. Cytotherapy. 2008; 10: 625-32

15. Tonn T, Schwabe D, Klingemann HG, Becker S, Esser R, Koehl U, et al. Treatment of patients with advanced cancer with the natural killer cell line NK-92. Cytotherapy. 2013; 15: 1563-70.

16. Imai $\mathrm{C}$, Iwamoto $\mathrm{S}$, Campana $\mathrm{D}$. Genetic modification of primary natural killer cells overcomes inhibitory signals and induces specific killing of leukemic cells. Blood. 2005; 106: 376-83.

17. Boissel L, Betancur $\mathrm{M}$, Wels WS, Tuncer $\mathrm{H}$, Klingemann $\mathrm{H}$. Transfection with mRNA for CD19 specific chimeric antigen receptor restores NK cell mediated killing of CLL cells. Leuk Res. 2009; 33: 1255-9.

18. Altvater B, Landmeier S, Pscherer S, Temme J, Schweer K, Kailayangiri S, et al. 2B4 (CD244) signaling by recombinant antigen-specific chimeric receptors costimulates natural killer cell activation to leukemia and neuroblastoma cells. Clin Cancer Res. 2009; 15: 4857-66.

19. Uherek C, Tonn T, Uherek B, Becker S, Schnierle B, Klingemann HG, et al. Retargeting of natural killer-cell cytolytic activity to ErbB2expressing cancer cells results in efficient and selective tumor cell destruction. Blood. 2002; 100: 1265-73.

20. Schönfeld K, Sahm C, Zhang C, Naundorf S, Brendel C, Odendahl $\mathrm{M}$, et al. Selective inhibition of tumor growth by clonal NK cells expressing an ErbB2/HER2-specific chimeric antigen receptor. Mol Ther. $2015 ; 23: 330-8$. 
21. Zhang C, Burger MC, Jennewein L, Genßler S, Schönfeld K, Zeiner $\mathrm{P}$, et al. ErbB2/HER2-specific NK cells for targeted therapy of glioblastoma. J Natl Cancer Inst. 2016; 108: djv375. doi: 10.1093/ jnci/djv375.

22. Sutlu T, Nystrom S, Gilljam M, Stellan B, Applequist SE, Alici E. Inhibition of intracellular antiviral defense mechanisms augments lentiviral transduction of human natural killer cells: implications for gene therapy. Hum Gene Ther. 2012; 23: 1090-100.

23. Maki G, Klingemann HG, Martinson JA, Tam YK. Factors regulating the cytotoxic activity of the human natural killer cell line, NK-92. J Hematother Stem Cell Res. 2001; 10: 369-83.

24. Sahm C, Schönfeld K, Wels WS. Expression of IL-15 in NK cells results in rapid enrichment and selective cytotoxicity of genemodified effectors that carry a tumor-specific antigen receptor. Cancer Immunol Immunother. 2012; 61: 1451-61.

25. Müller T, Uherek C, Maki G, Chow KU, Schimpf A, Klingemann $\mathrm{HG}$, et al. Expression of a CD20-specific chimeric antigen receptor enhances cytotoxic activity of NK cells and overcomes NK-resistance of lymphoma and leukemia cells. Cancer Immunol Immunother. 2008; 57: 411-23.

26. Esser R, Muller T, Stefes D, Kloess S, Seidel D, Gillies SD, et al. NK cells engineered to express a GD2 -specific antigen receptor display built-in ADCC-like activity against tumor cells of neuroectodermal origin. J Cell Mol Med. 2012; 16: 569-81.

27. Chu J, Deng Y, Benson DM, He S, Hughes T, Zhang J, et al. CS1specific chimeric antigen receptor (CAR)-engineered natural killer cells enhance in vitro and in vivo antitumor activity against human multiple myeloma. Leukemia. 2014; 28: 917-27.

28. Han J, Chu J, Keung Chan W, Zhang J, Wang Y, Cohen JB, et al. CAR-Engineered NK cells targeting wild-type EGFR and EGFRvIII enhance killing of glioblastoma and patient-derived glioblastoma stem cells. Sci Rep. 2015; 5: 11483. doi: 10.1038/srep11483.

29. Vivier E, Raulet DH, Moretta A, Caligiuri MA, Zitgovel L, Lanier LL, et al. Innate or Adaptive Immunity? The Example of Natural Killer Cells. Science. 2011; 331: 44-9.

30. Trinchieri, G. Biology of natural killer cells. Adv Immunol. 1989; 47: 187-376.

31. Vivier E, Nunes JA, Vely F. Natural killer cell signaling pathways. Science. 2004; 306: 1517-9.

32. Lanier LL. NK cell recognition. Annu Rev Immunol. 2005; 23: 22574.

33. Vivier E, Tomasello E, Baratin M, Walzer T, Ugolini S. Functions of natural killer cells. Nat Immunol. 2008; 9: 503-10.

34. Raulet DH, Vance RE. Self-tolerance of natural killer cells. Nat Rev Immunol. 2006; 6: 520-31. Yokoyama WM, Plougastel BF. Immune functions encoded by the natural killer gene complex. Nat Rev Immunol.

35. Parham P. MHC class I molecules and KIRs in human history, health and survival. Nat Rev Immunol. 2005; 5: 201-14.

36. Kärre K, Ljunggren HG, Piontek G, Kiessling, R. Selective rejection of $\mathrm{H}$ - 2-deficient lymphoma variants suggests alternative immune defense strategy. Nature. 1986; 319: 675-8.

38. Karlhofer FM, Ribaudo RK, Yokoyama WM. MHC Class I Alloantigen Specificity of Ly-49+ IL-2-Activated Natural Killer Cells. Nature. 1992; 358: 66-70.

39. Moretta A, Bottino C, Vitale M, Pende D, Biassoni R, Mingari MC, et al. Receptors for HLA class-I molecules in human natural killer cells. Annu Rev Immunol. 1996; 14: 619-48.

40. Raulet DH, Guerra N. Oncogenic stress sensed by the immune system: role of natural killer cell receptors. Nat Rev Immunol. 2009; 9: 56880.

41. Orange JS. Human natural killer cell deficiencies. Curr Opin Allergy Clin Immunol. 2006; 6: 399-409.
42. Berke G. The CTL's kiss of death. Cell. 1995; 81: 9-12.

43. Kim S, Iizuka K, Aguila HL, Weissman IL, Yokoyama WM. In vivo natural killer cell activities revealed by natural killer celldeficient mice. Proc Natl Acad Sci USA. 2000; 97: 2731-6.

44. Mocikat R, Braumuller H, Gumy A, Egeter O, Ziegler H, Reusch $\mathrm{U}$, et al. Natural killer cells activated by MHC class I(low) targets prime dendritic cells to induce protective CD8 T cell responses. Immunity. 2003; 19: 561-9.

45. Smyth MJ, Cretney E, Kelly JM, Westwood JA, Street SE, Yagita H, et al. Activation of NK cell cytotoxicity. Mol Immunol. 2005; 42: 501-10.

46. Tripp CS, Wolf SF, Unanue ER. Interleukin 12 and tumor necrosis factor alpha are costimulators of interferon gamma production by natural killer cells in severe combined immunodeficiency mice with listeriosis, and interleukin 10 is a physiologic antagonist. Proc Natl Acad Sci USA. 1993; 90: 3725-9.

47. Wallach D, Fellous M, Revel M. Preferential effect of gamma interferon on the synthesis of HLA antigens and their mRNAs in human cells. Nature. 1982; 299: 833-36.

48. FilipeSantos O, Bustamante J, Chapgier A, Vogt G, de Beaucoudrey $\mathrm{L}$, Feinberg $\mathrm{J}$, et al. Inborn errors of IL12/23 and IFNgammamediated immunity: molecular, cellular, and clinical features. Semin Immunol. 2006; 18: 347-61.

49. Maher SG, RomeroWeaver AL, Scarzello AJ, Gamero AM. Interferon: cellular executioner or white knight? Curr Med Chem. 2007; 14: 1279-89.

50. Cooper MA, Fehniger TA, Turner SC, Chen KS, Ghaheri BA, Ghayur $\mathrm{T}$, et al. Human natural killer cells: a unique innate immunoregulatory role for the CD56(bright) subset. Blood. 2001; 97: 3146-51.

51. Walzer T, Jaeger S, Chaix J, Vivier E. Natural killer cells: from CD3() NKp46(+) to postgenomics metaanalyses. Curr Opin Immunol. 2007; 19: 365-72.

52. Romagnani C, Juelke K, Falco M, Morandi B, D'Agostino A, Costa $\mathrm{R}$, et al. CD56brightCD16 killer Iglike receptorNK cells display longer telomeres and acquire features of CD56dim NK cells upon activation. J Immunol. 2007; 178: 4947-55.

53. Chan A, Hong DL, Atzberger A, Kollnberger S, Filer AD, Buckley $\mathrm{CD}$, et al. CD56bright human NK cells differentiate into CD56dim cells: role of contact with peripheral fibroblasts. J Immunol. 2007; 179: 89-94.

54. Ouyang Q, Baerlocher G, Vulto I, Lansdorp PM. Telomere length in human natural killer cell subsets. Ann NY Acad Sci. 2007; 1106: 240-52.

55. Takahashi E, Kuranaga N, Satoh K, Habu Y, Shinomiya N, Asano $\mathrm{T}$, et al. Induction of CD16+ CD56bright NK cells with antitumor cytotoxicity not only from CD16 CD56bright NK cells but also from CD16 CD56dim NK cells. Scand J Immunol. 2007; 65: 12638 .

56. Caliguiri MA. Human natural killer cells. Blood. 2008; 112: 4619.

57. Klingemann HG. Cellular therapy of cancer with natural killer cellswhere do we stand? Cytotherapy. 2013; 15: 1185-94.

58. Huntington ND, Vosshenrich CA, Di Santo JP. Developmental pathways that generate natural-killer-cell diversity in mice and humans. Nat Rev Immunol. 2007; 7: 703-14.

59. Guillerey C, Huntington ND, smyth MJ. Targeting natural killer cells in cancer immunotherapy. Nat Immunol. 2016; 17: 1025-36.

60. Voskoboinik I, Smyth MJ, Trapani JA. Perforin-mediated target-cell death and immune homeostasis. Nat Rev Immunol. 2006; 6: 94052 .

61. Sungur CM, Murphy WJ. Positive and negative regulation by NK cells in cancer. Crit Rev Oncog. 2014; 19: 57-66. 
62. Iannello A, Thompson TW, Ardolino M, Lowe SW, Raulet DH. p53dependent chemokine production by senescent tumor cells supports NKG2D-dependent tumor elimination by natural killer cells. J Exp Med. 2013; 210: 2057-69.

63. Becker PS, Suck G, Nowakowska P, Ullrich E, Seifried E, Bader P, et $a l$. Selection and expansion of natural killer cells for NK cell-based immunotherapy. Cancer Immunol Immunother. 2016; 65: 477-84.

64. Knorr DA, Bachanova V, Verneris MR, Miller JS. Clinical utility of natural killer cells in cancer therapy and transplantation. Semin Immunol. 2014; 26: 161-72.

65. Parkhurst MR, Riley JR, Dudley ME, Rosenberg SA. Adoptively transferred autologous natural killer cells persist in circulation but do not mediate tumor regression. Clin Canc Res. 2011; 17 : 6287-97.

66. Krause SW, Gastpar R, Andresen R, Gross C, Ullrich H, Thonigs G, et al. Treatment of colon cancer patients with ex vivo heat shock protein 70 peptide-activated, autologous natural killer cells: a clinical phase I trial. Clin Cancer Res. 2004; 10: 3699-707.

67. Motohashi S, Ishikawa A, Ishikawa E, Otsuji M, Iizasa T, Haoaka H, et al. A phase I study of ex vivo expanded natural killer T cells in patients with advanced and recurrent non-small lung cancer. Clin Cancer Res. 2006; 12: 6079-86.

68. Koepsell SA, Miller JS, McKenna DH Jr. Natural killer cells: a review of manufacturing and clinical utility. Transfusion. 2013; 53: 404-10.

69. McKenna DH Jr, Sumstad D, Bostrom N, Kadidlo DM, Fautsch S, McNearney $\mathrm{S}$, et al. Good manufacturing practices production of natural killer cells for immunotherapy: a six year single-institution experience. Transfusion. 2007; 47: 520-8.

70. Boissel L, Tuncer HH, Betancur M, Wolfberg A, Klingemann H. Umbilical cord mesenchymal stem cells increase expansion of cord blood natural killer cells. Biol Blood Marrow Transplant. 2008; 14: 1031-8.

71. Lapteva N, Durett AG, Sun J, Rollins L, Dandekar V, Mei Z, et al. Large-scale ex vivo expansion and characterization of natural killer cells for clinical application. Cytotherapy. 2012; 14: 1131-43.

72. Ljunggren HG, Malmberg KJ. Prospects for the use of NK cells in immunotherapy of human cancer. Nat Rev Immunol. 2007; 7: 32939.

73. Clausen J, Wolf D, Petzer AL, Gunsilius E, Schumacher P, Kircher $\mathrm{B}$, et al. Impact of natural killer cell dose and donor killer-cell immunoglobulin-like receptor (KIR) genotype on outcome following human leucocyte antigen-identical haematopoietic stem cell transplantation. Clin Exp Immunol. 2007; 148: 520-8.

74. Tanaka M, Kobayashi S, Numata A, Tachibana T, Takasaki H, Maruta $\mathrm{A}$, et al. The impact of the dose of natural killer cells in the graft on severe acute graft-versus-host disease after unrelated bone marrow transplantation. Leuk Res. 2012; 36: 699-703.

75. Locatelli F, Moretta F, Brescia L, Merli P. Natural killer cells in the treatment of high-risk acute leukaemia. Semin Immunol. 2014; 26 : 173-9.

76. Domogala A, Madrigal J, Saudemont A. Natural killer cell immunotherapy: from bench to bedside. Front Immunol. 2015; 6: 264. doi:10.3389/fimmu.2015.00264.

77. Xing D, Ramsay A, Gribben JG, Decker WK, Burks JK, Munsell $\mathrm{M}$, et al. Cord blood natural killer cells exhibit impaired lytic immunological synapse formation that is reversed with IL-2 exvivo expansion. J Immunother. 2010; 33: 684-96.

78. Shah N, Martin-Antonio B, Yang H, Ku S, Lee DA, Cooper LJ, et al. Antigen presenting cell-mediated expansion of human umbilical cord blood yields log-scale expansion of natural killer cells with anti-myeloma activity. PLoS ONE. 2013; 8: e76781. doi: 10.1371/ journal.pone.0076781.
79. Blum KS, Pabst R. Lymphocyte numbers and subsets in the human blood. Do they mirror the situation in all organs? Immunol Lett. 2007; 108: 45-51.

80. Klingemann H, Grodman C, Cutler E, Duque M, Kadidlo D, Klein A, et al. Autologous stem cell transplant recipients tolerate haploidentical related-donor natural killer cell enriched infusions. Transfusion. 2013; 53: 412-8.

81. Klingemann H-G, Martinson J. Ex vivo expansion of natural killer cells for clinical application. Cytotherapy. 2004; 6: 15-22.

82. Yengar R, Handgretinger R, Babarin-Dorner A, Leimig T, Otto M, Geiger TL, et al. Purification of human natural killer cells using a clinical-scale immunomagnetic method. Cytotherapy. 2003; 5: 47984.

83. Grzywacz B, Kataria N, Sikora M, Oostendorp RA, Dzierzak EA, Blazar BR, et al. Coordinated acquisition of inhibitory and activating receptors and functional properties by developing human natural killer cells. Blood. 2006; 108: 3824-33.

84. Domogala A, Madrigal J, Saudemont A. Cryopreservation has no effect on function of natural killer cells differentiated in vitro from umbilical cord blood CD34+ cells. Cytotherapy. 2016; 18: 754-9.

85. Luhm J, Brand JM, Koritke P, Hoppner M, Kirchner H, Frohn C. Large-scale generation of natural killer lymphocytes for clinical application. J Hematother Stem Cell Res. 2002; 11: 651-7.

86. Siegler U, Meyer-Monard S, Jorger S, Stern M, Tichelli A, Gratwohl $\mathrm{A}$, et al. Good manufacturing practice-compliant cell sorting and large-scale expansion of single KIR-positive alloreactive human natural killer cells for multiple infusions to leukemia patients. Cytotherapy. 2010; 12: 750-63.

87. Meyer-Monard S, Passweg J, Siegler U, Kalberer C, Koehl U, Rovo A, et al. Clinical-grade purification of natural killer cells in haploidentical hematopoietic stem cell transplantation. Transfusion. 2009; 49: 362-71.

88. Fujisaki H, Kakuda H, Shimasaki N, Imai C, Ma J, Lockey T, et al. Expansion of highly cytotoxic human natural killer cells for cancer cell therapy. Cancer Res. 2009; 69: 4010-7.

89. Berg M, Lundqvist A, McCoy P Jr, Samsel L, Fan Y, Tawab A, et al. Clinical-grade ex vivo-expanded human natural killer cells upregulate activating receptors and death receptor ligands and have enhanced cytolytic activity against tumor cells. Cytotherapy. 2009; 11: 341-55.

90. Lundqvist A, Yokoyama H, Smith A, Berg M, Childs R. Bortezomib treatment and regulatory T-cell depletion enhance the antitumor effects of adoptively infused NK cells. Blood. 2009; 113: 6120-7.

91. Miller JS, Soignier Y, Panoskaltsis-Mortari A, McNearney SA, Yun GH, Fautsch SK, et al. Successful adoptive transfer and in vivo expansion of human haploidentical NK cells in patients with cancer. Blood. 2005; 105: 3051-7.

92. Gong JH, Maki G, Klingemann HG. Characterization of a human cell line (nk-92) with phenotypical and functional characteristics of activated natural killer cells. Leukemia. 1994; 8: 652-8.

93. Tam YK, Martinson JA, Doligosa K, Klingemann HG. Ex vivo expansion of the highly cytotoxic human natural killer-92 cell-line under current good manufacturing practice condi- tions for clinical adoptive cellular immunotherapy. Cytotherapy. 2003; 5: 259-72.

94. Matsuo Y, Drexler HG. Immunoprofiling of cell lines derived from natural killer-cell and natural killer-like t-cell leukemia-lymphoma. Leuk Res. 2003; 27: 935-45.

95. NN. The key to unlocking CARs. Nat Biotechnol. 2017; 35: 889. doi: 10.1038/nbt.3993.

96. Bhat R, Watzl C. Serial killing of tumor cells by human natural killer cells--enhancement by therapeutic antibodies. PLoS One. 2007; 2: e326. doi: 10.1371/journal.pone.0000326. 
97. Klingemann H. Are natural killer cells superior CAR drivers. Oncoimmunol. 2014; 3: e28147. doi: 10.4161/onci.28147.

98. Glienke W, Esser R, Priesner C, Suerth JD, Schambach A, Wels WS, et al. Advantages and applications of CAR-expressing natural killer cells. Front Pharmacol. 2015; 6: 21. doi: 10.3389/ fphar.2015.00021.

99. Daldrup-Link HE, Meier R, Rudelius M, Piontek G, Piert M, Metz $\mathrm{S}$, et al. In vivo tracking of genetically engineered, anti-HER $2 /$ neu directed natural killer cells to HER2/neu positive mammary tumors with magnetic resonance imaging. Eur Radiol. 2005; 15: 4-13.

100. Romanski A, Uherek C, Bug G, Seifried E, Klingeman H, Wels WS, et al. CD19-CAR engineered NK-92 cells are sufficient to overcome NK cell resistance in B-cell malignancies. J Cell Mol Med. 2016; 20: $1287-94$

101. Velardi A. Natural killer cell alloreactivity 10 years later. Curr Opin Hematol. 2012; 19: 421-6.

102. Raffaghello L, Prigione I, Airoldi I, Camoriano M, Levreri I, Gambini $\mathrm{C}$, et al. Downregulation and/or release of NKG2D ligands as immune evasion strategy of human neuroblastoma. Neoplasia. 2004; 6: 558-68
103. Holdenrieder S, Eichhorn P, Beuers U, Samtleben W, Stieber P, Nagel $\mathrm{D}$, et al. Soluble NKG2D ligands in hepatic autoimmune diseases and in benign diseases involved in marker metabolism. Anticancer Res. 2007; 27: 2041-5.

104. Kloess S, Huenecke S, Piechulek D, Esser R, Koch J, Brehm C, et al. IL-2-activated haploidentical NK cells restore NKG2D-mediated NK-cell cytotoxicity in neuroblastoma patients by scavenging of plasma MICA. Eur J Immunol. 2010; 40: 3255-67.

105. Sutlu T, Alici E. Natural killer cell-based immunotherapy in cancer: current insights and future prospects. J Intern Med. 2009; 266: 154 81.

106. Lee JH, Kim JS, Kim KH, Choi JE, Ji AY, Ting JT, et al. Comparison of cytotoxic dynamics between cytokine-induced killer cells and natural killer cells at the single cell level. J Immunol 2017; 198 (Supp 1): 198.12.

107. Rubnitz JE, Inaba H, Ribeiro RC, Pounds S, Rooney B, Bell T, et al. NKAML: a pilot study to determine the safety and feasibility of haploidentical natural killer cell transplantation in childhood acute myeloid leukemia. J Clin Oncol. 2010; 28: 955-9.

108. Miller JS. Therapeutic applications: natural killer cells in the clinic. Hematology Am Soc Hematol Educ Program. 2013; 2013: 247-53. 